\title{
How to use blogs in your travel marketing channel mix
}

\author{
L. Huang \\ Graduate Institute of Travel and Tourism Management, \\ Kaohsiung Hospitality College, Taiwan, R.O.C.
}

\begin{abstract}
This study explores travel blog marketing channel strategies and the conceptual business model of the marketing channel from the travel agency practitioners' perspective. A three-round Delphi research design was adopted. According to the research, Taiwanese travel agencies consider four external environment forces, five internal motivations for investment, four developing differentiated strategies, and four channel performance measurement indicators. This study is quite innovative in that no related studies so far have analyzed nor tried to discern the issues of travel blog marketing channel strategies and the business model of travel blog for travel agencies. Finally, the construct of a travel blog marketing channel strategy model for Taiwan's travel agency industry can address practical and theoretical needs.
\end{abstract}

Keywords: travel blog, marketing channel, channel management, travel agency, Delphi.

\section{Introduction}

The continuing rise of the Internet as a communications tool for travel organizations presents challenges for travel marketing activities and tourism enterprises that use blogs as part of their business strategy. Blogs that are interlinked with or integrated into a supplier's website may therefore essentially contribute to an online booking at the later stage of a traveler's online information search and travel planning behavior [1]. Blogs in particular have also proliferated rapidly in the last few years and are growing in popularity [2-4]. It is clear that blogs will continue to grow both as a medium for telling people about trips and as a source of information for potential travelers [5]. 
Some research has been done concerning blogging issues in tourism and other retailing businesses $[1,3,5-8]$, yet there lacks research exploring the related issues in the travel industry. Ironically, there appears to have been no empirical or theoretical development of the travel blogging channel strategic model for the travel agency industry.

\section{Literature review}

For travel agencies, the emphasis is still on the traditional marketing communication channels such as print media [9] and telephone [10]. On other hand, more and more consumers continue to gain information through the Internet while still preferring to use traditional distribution channels and continuing to appreciate things done the old, traditional way [11-13].

Web blogs in general have become among the more popular forms of online consumer-opinion platforms [14]. In Taiwan, more and more travel blogs have been set up, not only to open up new marketing channels, but also to create a revolutionary business model for future profit.

\subsection{Enhancing the competitive advantage under external environment forces}

In volatile environments, firms have to make use of a large set of channels for minimizing risks [15]. The more competitive companies tend to scrutinize the environment more acutely in search of new opportunities and are more likely to respond proactively to environmental changes [16]. Moreover, external factors might have an impact on the design and development of the business model. Therefore, with the rapid growth in the numbers of travel blogs, an increasing number of travel agencies are eager to build the travel blogging marketing channel in order to acquire competitive advantages.

Travel agencies developing new channels must adapt to this new environment where the external environmental major forces stem from Porter's Five-ForcesModel such as competitors, market conditions, etc. It is good business sense to monitor what is being said about your travel agency's service or product in the blogosphere. Although Walle [17] argues that a key strength of travel agencies is their ability to continuously provide personal information and advice to travelers, travel agency practitioners still try to explore how the travel blogging channel can be effectively developed as comparative competitive advantages under external environment forces.

\subsection{Internal motivations for investment in travel blogging channels}

The structure of the marketing channel reflects the different market segments drawn to or targeted by each operation and the relative importance of them. Researchers [18-20] take both views into consideration in that traditional and ecommerce distribution channels supplement each other to serve travelers to their greatest satisfaction. The choice of direct or indirect sales and the selection 
of appropriate marketing channels essentially involve a tradeoff between market coverage and cost [21]. In order to increase market share, becoming more technologically orientated is inevitable. Thus, the combination of traditional marketing channels with e-commerce, such as travel blog channels, makes it possible to optimize consumer convenience and increase their scope to a wider audience.

Travel blogs can create the brand name of products and build up the publicity of company, facilitate global marketing, add transition rates through online platforms, obtain personal data from individual consumers [22], focus on a specific niche [23], provide a lower cost due to labor savings, offer multiple choices in travel services, and market travel products freely. In short, the main reasons for investment in travel blogs are that they are cheap, they are easy to use and require little training, knowledge sharing, and learning improvement, they develop contacts/networks, and they create "an R\&D center that is always open" [24]. All these trends are leading travel agency entrepreneurs to wonder whether blogs can generate meaningful revenues or, for that matter, offer a legitimate alternative to the business models of existing travel agencies.

\subsection{Developing differentiated strategies through the travel blog channel}

Hospitality managers may face increasing challenges in developing new resources, implementing effective and efficient strategies, and attaining high market performance. These changes in the marketplace have forced firms to seek new opportunities to differentiate their products and services [25]. Three strategies are used to locate relevant blogs: (1) To use the search term. (2) To locate entries. (3) To locate special interest websites [5]. Concisely, a blog can be differentiated from a website, because it is easier to create and update, and blogging is viewed as an integral part of the company's management strategy [26].

On a practical level, travel agencies try to effectively engage in blog marketing with businesses so as to develop e-business competence and estrategies [27]. Although the opportunities to use blogs for direct product distribution may be more limited than communication and promotion functions, blogs can be extremely useful as part of a defensive strategy in the tourism and hospitality industry [1]. This includes generating positive publicity and providing responses and counter arguments to negative comments as a way of damage control [28]. Different strategies have different requirements for success, and it follows that a performance evaluation should be tailored to strategic orientation [29]. Performance measurement systems also improve the strategic competitiveness of organizations [30].

\subsection{Seizing the expected performance through a travel blogging channel strategy}

Profit and growth are frequently used as criteria in the context of measurement [31]. Managing for competitive advantage in a multi-channel environment means 
that managers are involved with customer interactions across multiple channels [32]. Existing literature has plotted the increasing use by consumers of online recommendations or e-word of mouth [33]. With the Internet playing an increasingly prominent role in marketing activities, the importance of travel blogs has certainly become evident.

Travel blogs indeed generate revenue through links to direct booking platforms [34], many tourism professionals believe that companies should actively monitor the blogosphere on a constant basis and look for companyrelated comments. Monitoring blogs can be an effective way to detect what is being said about one's own company and competitors [1]. This is what makes Taiwan's travel agency sector an ideal setting to study the determinants of adopting a travel blogging marketing channel strategy, in order to promote a high level of branding image. The successful travel blog mechanism of travel agencies will need to adopt a strategy that targets market share, given its impact on the organization's performance.

\section{Objectives of this study}

This study examines the travel blogging marketing channel in particular, analyzing the optimal strategy for travel agencies. Research outcomes should shed light on the understanding of how travel blogging strategies can create maximum profits. Consequently, there are three specific objectives of this study.

(1). Conduct a qualitative approach on the target travel agencies. Their responses provide much better insight into the external environment forces, internal investment motivations of adopting t-blog marketing channel, and the travel blogging channel performances.

(2). Identify the underlying determinants of adopting a t-blog marketing channel strategy for travel agencies to discover better practices for upgrading channel effectiveness and pursuing competitive advantages.

(3). Provide meaningful methods to practitioners or marketers of travel agencies to increase the t-blog marketing channel's ability to attract floating customers, thereby achieving economies of scale.

\section{Methods}

To fulfill the objectives of this study, qualitative interviews through a Delphi study research design are adopted that focus on primary travel agencies in order to obtain more in-depth information and to identify the critical variables. As there is no previous research on travel blog channel issues in Taiwanese travel agencies, exploratory research is employed herein. Both primary and secondary data are therefore essential. This study also tries to discern the variables relating to external environment forces, internal motivation for investment, differentiated channel strategies, and travel blogging channel performances. Thus, the paper uses a three-round Delphi survey method. Based on the above research design, a 


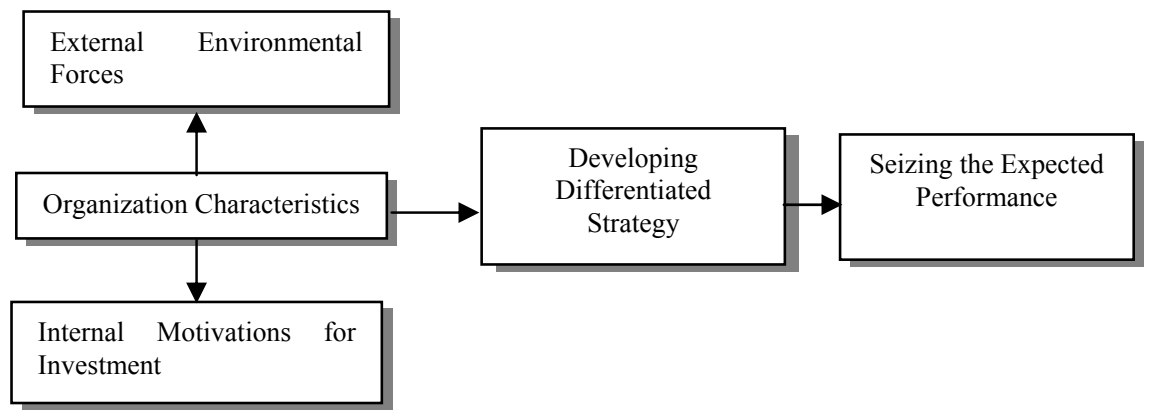

Figure 1: Developing competitive advantages through a travel blog marketing channel.

research framework develops competitive advantages through a travel blog marketing channel framework (see Figure 1).

\subsection{Sampling}

The research adopting a Delphi survey in the beginning was conducted on 11 primary travel agencies focusing on the travel blogging marketing channel in Taiwan's travel market, including: Set Tour (www.settour.com.tw), Lion Travel (www.liontravel.com.tw), Royal Jetway Express (www.royaljetway.com.tw), Star Travel (www.startravel.com.tw), Dragon Tours (www.dragontr.com.tw/), China Times Travel Service (www.cts-travel.com.tw), Artisan Tour (www.artisan.com.tw), Uno Tour (www.unotour.com.tw), Perfect Tours (www.perfect.com.tw), Spring Wind (www.springwind.com.tw), and Ocean Star (www.oceanstar.com.tw). This survey was carried out over a three-month period from July 2009 to September 2009. Finally, this study group consists of 11 final snowball sampling target experts who are directly involved with travel agency management plus practitioners, including 11 major travel agent CEOs. A threeround Delphi study using the above 11 experts in the field of blogging channel management was thus used to develop, validate, and prioritize a baseline list of potential evaluation criteria of the optimal travel blogging channel strategic model dimension.

\subsection{Data analysis}

The study adopts a three-round Delphi survey, combining both qualitative and quantitative approaches and using experts in the field of t-blog travel marketing channel and marketing channel management. In order to improve the indicators' validity, convergence, consensus, and concordance, there are four criteria that have been put into place: (1). the standard deviation value of each attribute is not greater than $1 ;(2)$. the value of a mean score rounded down 0.4 or rounded up 0.5 in units is equal to the value of the mode; (3). the value of the quartile deviation ranges from 0 to 0.6 , with less than 0.6 indicating strong consensus, 
Table 1: Three-round Delphi result of the travel blog marketing channel model.

\begin{tabular}{|c|c|c|c|c|c|c|c|}
\hline \multirow[b]{2}{*}{ Dimension } & \multirow[b]{2}{*}{ Factor } & \multicolumn{6}{|c|}{ Number: 11 / Response Rate: 0.92} \\
\hline & & Mean & Mode & S.D. & Q.D. & $\begin{array}{l}\text { Rank- } \\
\text { ing }\end{array}$ & $\begin{array}{l}\text { Kenda- } \\
\text { Il's W }\end{array}$ \\
\hline \multirow{4}{*}{$\begin{array}{l}\text { External } \\
\text { Environme } \\
\text { ntal } \\
\text { Forces }\end{array}$} & increasing blog users $\left(\boldsymbol{e}_{1}\right)$ & $\begin{array}{c}4.8 \\
2\end{array}$ & 5 & $\begin{array}{c}0.4 \\
0\end{array}$ & 0 & 1 & \multirow{4}{*}{0.81} \\
\hline & $\begin{array}{l}\text { threat of substitute } \\
\text { channels }\left(\boldsymbol{e}_{2}\right)\end{array}$ & $\begin{array}{c}4.7 \\
3\end{array}$ & 5 & $\begin{array}{c}0.4 \\
7\end{array}$ & 0.50 & 2 & \\
\hline & $\begin{array}{l}\text { competitive intensity from } \\
\text { industry incumbents }\left(\boldsymbol{e}_{3}\right)\end{array}$ & $\begin{array}{c}3.8 \\
2\end{array}$ & 4 & $\begin{array}{c}0.4 \\
0\end{array}$ & 0 & 3 & \\
\hline & $\begin{array}{lll}\text { bargaining } & \text { power } & \text { of } \\
\text { buyers }\left(\boldsymbol{e}_{4}\right) & & \end{array}$ & $\begin{array}{c}3.7 \\
3\end{array}$ & 4 & $\begin{array}{c}0.4 \\
7\end{array}$ & 0.50 & 4 & \\
\hline \multirow{5}{*}{$\begin{array}{l}\text { Internal } \\
\text { Motivations } \\
\text { for } \\
\text { Investment }\end{array}$} & $\begin{array}{ll}\text { increasing } & \text { customer } \\
\text { relationship }\left(\boldsymbol{m}_{1}\right)\end{array}$ & $\begin{array}{c}4.8 \\
2\end{array}$ & 5 & $\begin{array}{c}0.4 \\
0\end{array}$ & 0 & 1 & \multirow{5}{*}{0.69} \\
\hline & $\begin{array}{l}\text { strengthening promotion } \\
\text { effectiveness }\left(\boldsymbol{m}_{2}\right)\end{array}$ & $\begin{array}{c}4.7 \\
3\end{array}$ & 5 & $\begin{array}{c}0.4 \\
7\end{array}$ & 0.50 & 2 & \\
\hline & $\begin{array}{l}\text { expanding distribution } \\
\text { channels }\left(\boldsymbol{m}_{3}\right)\end{array}$ & $\begin{array}{c}4.5 \\
5\end{array}$ & 5 & $\begin{array}{c}0.5 \\
2 \\
\end{array}$ & 0.50 & 3 & \\
\hline & $\begin{array}{ll}\text { improving } & \text { external } \\
\text { censorship }\left(\boldsymbol{m}_{4}\right) & \\
\end{array}$ & $\begin{array}{c}4.1 \\
8\end{array}$ & 4 & $\begin{array}{c}0.4 \\
0\end{array}$ & 0 & 4 & \\
\hline & $\begin{array}{lll}\begin{array}{l}\text { reducing } \\
\left(\boldsymbol{m}_{5}\right)\end{array} & \text { R\&D } & \text { cost } \\
\end{array}$ & $\begin{array}{c}3.5 \\
5 \\
\end{array}$ & 4 & $\begin{array}{c}0.5 \\
2 \\
\end{array}$ & $\begin{array}{c}0.5 \\
0 \\
\end{array}$ & 5 & \\
\hline \multirow{4}{*}{$\begin{array}{l}\text { Developin } \\
\text { g } \\
\text { Differenti } \\
\text { ated } \\
\text { Strategy }\end{array}$} & $\begin{array}{l}\text { building a brand image } \\
\left(\boldsymbol{S}_{1}\right)\end{array}$ & $\begin{array}{c}4.9 \\
1 \\
\end{array}$ & 5 & $\begin{array}{c}0.3 \\
0\end{array}$ & 0 & 1 & \multirow{4}{*}{0.74} \\
\hline & $\begin{array}{l}\text { offering a superior product } \\
\left(\boldsymbol{S}_{2}\right)\end{array}$ & $\begin{array}{c}4.8 \\
2 \\
\end{array}$ & 5 & $\begin{array}{c}0.4 \\
0\end{array}$ & 0 & 2 & \\
\hline & $\begin{array}{l}\text { exploring customer- } \\
\text { specific solutions }\left(\boldsymbol{S}_{3}\right)\end{array}$ & $\begin{array}{c}4.0 \\
9\end{array}$ & 4 & $\begin{array}{c}0.3 \\
0\end{array}$ & 0 & 3 & \\
\hline & $\begin{array}{l}\text { developing new products } \\
\left(\boldsymbol{S}_{4}\right)\end{array}$ & $\begin{array}{c}3.8 \\
2\end{array}$ & 4 & $\begin{array}{c}0.4 \\
0\end{array}$ & 0 & 4 & \\
\hline \multirow{4}{*}{$\begin{array}{l}\text { Seizing } \\
\text { the } \\
\text { Expected } \\
\text { Performa } \\
\text { nce }\end{array}$} & $\begin{array}{l}\text { generating buzz and } \\
\text { interest }\left(\boldsymbol{P}_{1}\right)\end{array}$ & $\begin{array}{c}4.8 \\
2\end{array}$ & 5 & $\begin{array}{c}0.4 \\
0\end{array}$ & 0 & 1 & \multirow{4}{*}{0.66} \\
\hline & increasing sales $\left(\boldsymbol{P}_{2}\right)$ & $\begin{array}{c}4.7 \\
3 \\
\end{array}$ & 5 & $\begin{array}{c}0.4 \\
7\end{array}$ & 0.50 & 2 & \\
\hline & $\begin{array}{l}\text { encouraging repeat visits } \\
\text { to the blog and associated } \\
\text { websites }\left(\boldsymbol{P}_{3}\right)\end{array}$ & $\begin{array}{c}4.1 \\
8\end{array}$ & 4 & $\begin{array}{c}0.4 \\
1\end{array}$ & 0 & 3 & \\
\hline & $\begin{array}{l}\text { improving page ranks with } \\
\text { the major search engines } \\
\left(\boldsymbol{P}_{4}\right)\end{array}$ & $\begin{array}{c}3.6 \\
4\end{array}$ & 4 & $\begin{array}{c}0.5 \\
0\end{array}$ & 0.50 & 4 & \\
\hline
\end{tabular}


0 indicating a perfect consensus; and ranges from 0.6 to 1 , with 1 indicating no consensus [36]; and (4). Kendall's W coefficient of concordance has a value of $\mathrm{W}$ ranging from 0 to 1 , with 0 indicating no consensus, and 1 indicating perfect consensus between lists [37]. If any attribute does not match two of the four above criteria, then the next round of the Delphi survey is begun. The experts' data was then analyzed, ending with results in Table 1.

\section{Findings}

The results of the Delphi analysis yield several insights that confirm previous findings and shed light on the future of travel agencies enhancing their competitive advantage through travel blogging marketing channel strategies under several external environment forces.

\subsection{How do external environment forces impact the travel blog marketing channel?}

Through a travel blog, a travel agency's marketing managers or sales team can quickly target the customer as a key method of gaining a competitive advantage. Seizing any opportunity can help highlight special target customers around one's own travel blogs and allows a travel agency's t-blogs to be a channel for casting a spotlight on their performance and ideas. Adopting an appropriate strategic model is a key source of competitive advantage and mitigates the threat of substitute channels from travel blogging channels. Specifically, travel agency practitioners can decrease the bargaining power of buyers, and hence the indirect sharing of travel blog experiences is used as a powerful way to reduce external environment uncertainty regarding a travel product or service being intangible. Findings indicate that a blog is an external censorship on marketing activities and is able to push forth successful marketing channel strategies of travel agencies and reduce external risk and adopt efficiency motives, in order to build competitive advantages.

\subsection{Does the travel blog marketing channel realize the internal investment motivation?}

Travel agency practitioners are faced with many questions that impinge upon how to build up a travel blogging marketing channel under profitable investment considerations. They often face difficulty in finding the right details about all aspects of channel management, and then they try to gather an optimal marketing channel mix from various channels. Many major travel agencies are now aggressively investigating travel blogs by utilizing one of a variety of marketing channel strategies to lure travelers to book and shop at their websites. Travel blogs are likely to have an increasing influence on word-of-mouth communication, the strengthening of customer relationships, promotion effectiveness, improving external censorship, and reducing R\&D costs. Therefore, in order to have a business advantage against their competitors, travel 
agencies try to expand their marketing channel by employing travel blogging so as to maximize yields.

\subsection{What is a differentiated strategy through a travel blog marketing channel?}

The usefulness of travel blogs as a crucial marketing channel will depend on the travel users' view and trust toward the blogging contents in order to develop an e-brand image. Some travel agencies are developing differentiated strategies to offer a superior product and customer-specific solutions. A travel blog may not attain abundant revenues in the short term, but the role of travel blogs has successfully been played out in R\&D of differentiated products and services. Travel blogs should not be ignored as one of many channels available for maximizing revenue. Eventually, the practical implications of the travel blogging marketing channel for practitioners must be critically understood to make use of it as a marketing channel by which executives not only can engage directly with all their internal communications within companies, but also indirectly build up a differentiated position within all competitors.

\subsection{Are there clearly defined performances in a travel blog marketing channel?}

For travel agency practitioners using the blog marketing channel to source profits, the effectiveness of travel blogging may be strengthened through several points: increased sales, page ranks with the major search engines, and generating buzz and interest. Finally, blog exposure attracts e-browsers and designs an appropriate blog mechanism that meets e-users' preferences in order to lure them to re-participate in travel blogging or associated website activities. Travel agencies adopt travel blogs in a strategic way to identify and monitor trends in a travel market, evaluate products or service standards, measure the performance of associated products or collaborators, and analyze competitors. Hence, for travel agency practitioners it is essential to evaluate the performances of travel blog marketing channels on their revenue management practices and determine how to benefit from it.

\section{Conclusions}

Effective marketing channel management is especially important for travel agencies, because of their perishable inventories. A travel blog, still in its initial phase and being a small segment of the total Taiwan travel market, is expected to grow by leaps and bounds between the traditional and e-commerce transactional models. Travel agency practitioners believe that the travel blog wave will profoundly affect the travel market. Consequently, more and more travel agencies are determining just how they are going to participate in, or compete with, this new marketing channel within the market. Therefore, it is very important to explore the determinants of adopting travel blogging strategies and business models in the travel agency industry. 
This study offers a conceptual overview of travel agency practitioner-focused travel blog marketing channel strategies based on the results of a three-round Delphi survey from major Taiwan travel agencies. The findings of this study should be useful to the travel agency practitioner in making decisions in order to effectively exploit the different marketing channel mix and travel blogging strategies for acquiring maximum profits. The study also identifies a portable business model of travel blog marketing channel nodes that are most important for travel agency marketing channel mix and offers forecasts regarding the optimal business model of a travel blog marketing channel that is of greatest importance. Future research needs to address the profitability of the travel blogging business model.

\section{References}

[1] Schmallegger, D. and Carson, D., Blogs in tourism: Changing approaches to information exchange. Journal of Vacation Marketing, 14(2), pp. 99-110, 2007.

[2] Pan, B., MacLaurin, T. and Crotts, J. C., Travel blog and the implications for destination marketing. Journal of Travel Research, 46(1), pp. 35-45, 2007.

[3] Mack, R. W., Blose, J. and Pan, B., Believe it or not: Credibility of blogs in tourism. Journal of Vacation Marketing, 14(2), pp.133-144, 2008.

[4] Tussyadiah, I. P. and Fesenmaier, D. R., Marketing places through firstperson stories-An analysis of Pennsylvania road tripper blog. Journal of Travel and Tourism Marketing, 25(3/4), pp. 299-311, 2008.

[5] Carson, D., The blogosphere as a market research tool for tourism destinations: A case study of Australia's Northern Territory. Journal of Vacation Marketing, 14(2), pp. 111-119, 2008.

[6] Lin, Y. S. and Huang, J. Y., Internet blogs as a tourism marketing medium: A case study. Journal of Business Research, 59(10), pp. 1201-1205, 2006.

[7] Thevenot, G., Blogging as a social media. Tourism and Hospitality Research, 7(3/4), pp. 287-289, 2007.

[8] Lundberg, M. C., A-word-of-mouth approach to informal information sharing among part-time and short-term employed front-line workers in tourism. Journal of Vacation Marketing, 14(1), pp. 23-39, 2008.

[9] Ozturan, M. and Roney, S., Internet use among travel agencies in Turkey: An exploratory study. Tourism Management, 25(2), pp. 259-266, 2004.

[10] Kim, D. Y., Hwang, Y. H. and Fesenmaier, D. R., Modeling tourism advertising effectiveness. Journal of Travel Research, 44(1), pp. 42-49, 2005.

[11] Lang, T. C., The effect of the Internet on travel consumer purchasing behavior and implications for travel agencies. Journal of Vacation Marketing, 6(4), pp. 368-385, 2000.

[12] Kim, D. Y., Lehto, X. Y. and Morrison, A. M., Gender differences in online travel information search: Implications for marketing communications on the Internet. Tourism Management, 28(2), pp. 423-433, 2007. 
[13] Nishimura, S., King, B. and Waryszak, R., The use of travel guidebooks by packaged and non-packaged Japanese travelers: A comparative study. Journal of Vacation Marketing, 13(4), pp. 291-310, 2007.

[14] Wenger, A., Analysis of travel bloggers' characteristics and their communication about Austria as a tourism destination. Journal of Vacation Marketing, 14(2), pp. 169-176, 2008.

[15] Coelho, F. and Easingwood, C., Determinants of multiple channel choice in financial services: An environmental uncertainty mode. Journal of Services Marketing, 19(4), pp. 199-211, 2005.

[16] Coelho, F. and Easingwood, C., A model of the antecedents of multiple channel usage. Journal of Retailing and Consumer Services, 15(1), pp. 3241, 2008.

[17] Walle, A., Tourism and Internet: Opportunities for direct marketing. Journal of Travel Research, 35(1), pp. 72-77, 1996.

[18] Law, R., Leung, K. and Wong, J., The impact of the Internet on travel agencies. International Journal of Contemporary Hospitality Management, 16(2), pp. 100-107, 2004.

[19] Bennett, M. M. and Lai, C. W. K., The impact of the Internet on travel agencies in Taiwan. Tourism and Hospitality Research, 6(1), pp. 8-23, 2005.

[20] Jun, S. H., Vogt, C. A. and Mackay, K. J., Relationships between travel information search and travel product purchase in pre-trip contexts. Journal of Travel Research, 45(3), pp. 266-274, 2007.

[21] Pearce, D. G. and Tan, R., Distribution channels for heritage and cultural tourism in New Zealand. Asia Pacific Journal of Tourism Research, 9(3), pp. 225-237, 2002.

[22] Kajewski, M. A., Emerging technologies changing our service delivery models. The Electronic Library, 25(4), pp. 420-429, 2007.

[23] Lee, S., Hwang, T. and Lee, H. H., Corporate blogging strategies of the Fortune 500 companies. Management Decision, 44(3), pp. 316-334, 2006.

[24] Garcia, H. F., Blogging 4 business report. Strategic Direction, 22(9), pp. 18-20, 2006.

[25] Singh, T., Jackson-Veron, L. and Cullinane, J., Blogging: A new play in your marketing game plan. Business Horizons, 51(4), pp. 281-292, 2008.

[26] Wyld, D. C., Management 2.0: A primer on blogging for executives. Management Research News, 31(6), pp. 448-483, 2008.

[27] Puhringer, S. and Taylor, A., A practitioner's report on blogs as a potential source of destination marketing intelligence. Journal of Vacation Marketing, 14(2), pp. 177-187, 2008.

[28] Building a blog strategy in hospitality: Grow customer relationships and direct online revenue, Hospitality Net. http://www.hospitalitynet.org/ news/4026867.html

[29] Olson, E. M. and Slater, S. F., The balanced scorecard, competitive strategy, and performance. Business Horizons, 45(3), pp. 11-16, 2002.

[30] Chenhall, R. H., Integrative strategic performance measurement systems, strategic alignment of manufacturing, learning and strategic outcomes: An 
exploratory study, Accounting. Organizations and Society, 30(5), pp. 395422, 2005.

[31] Hyder, A. S. and Abraha, D., Product and skills development in small- and medium-sized high-tech firms through international strategic alliances. Singapore Management Review, 26(2), pp. 1-24, 2004.

[32] Ganesh, J., Managing customer preferences in a multiple-channel environment using web services. International Journal of Retail and Distribution Management, 32(3), pp. 140-146, 2004.

[33] Bickart, B., Expanding the scope of word of mouth: Consumer to consumer information on the Internet. Advances in Consumer Research, 29(1), pp. 428-430, 2002.

[34] Sharda, N. and Ponnada, M., Tourism blog visualizer for better tour planning. Journal of Vacation Marketing, 14(2), pp. 157-167, 2008.

[35] Huang, C. Y., Chou, C. J. and Lin, P. C., Involvement theory in constructing bloggers' intention to purchase travel products, Tourism Management, 31(4), pp 513-526, 2010.

[36] Holden, M. C. and Wedman, J. F., Future issues of computer-mediated communication: The results of a Delphi study. Educational Technology, Research and Development, 41(4), pp. 5-24, 1993.

[37] Schmidt, R. C., Managing Delphi surveys using non parametric statistical techniques. Decision Sciences, 28(3), pp. 763-774, 1997. 